\title{
Potential Ocean Thermal Energy Conversion (OTEC) in Bali
}

\author{
Adrian Rizki Sinuhaji $\mathrm{a}^{*}$ \\ ${ }^{a}$ Geological Engineering Padjadjaran University, Jalan Raya Bandung-Sumedang,Bandung,Indonesia
}

\begin{abstract}
OTEC is a method for generating electricity which uses the temperature difference that exist between deep and shallow water with the minimal difference about $20^{\circ} \mathrm{C}$. This paper aim to determine the potential and the provision of new and renewable energy in Indonesia.OTEC is very compatible build in Indonesian sea because Indonesia is placed in equator teritory, a lot of island, strain and many difference of topography especially in North Bali Sea. A calculation ocean thermal distribution in Indonesia for OTEC is doing with statistics from ocean thermal surface.The maximum efficiency of carnot engine $\left(\eta_{\max }\right)$ is obtained in the North Bali Sea by 0.788813. Figures are better than other regions in the Indonesia. OTEC power production is renewable energy that could be a solution to produce electricity, and also can produce fresh water and cold water for agricultural and cooling purposes especially in the tourist area like Bali.
\end{abstract}

Keywords: OTEC, Bali, Temperature, Renewable Energy

\section{Introduction}

Indonesia, which has the largest population of all ASEAN countries, will became a net oil import in the early $21^{\text {st }}$ century. The Indonesia government has set up a long term energy plan aiming at energy diversification to reduce the country's dependence in oil. One of the renewable energy resources is the temperature gradient to exit in the sea, solar energy which creates this gradient and in particular Ocean Thermal Energy Conversion (OTEC).

OTEC uses the temperature difference that exists between deep and swallow water to run a heat engine. OTEC is an energy technology, which uses the ocean's natural temperature gradient to drive a turbine, which is connected to a generator.It is desirable that the temperature difference between the warm surface water and the cold deep water be at least $20^{\circ} \mathrm{C}\left(68^{\circ} \mathrm{F}\right)$.

North Bali Sea is area which excellent thermal potential of OTEC. North Bali Sea is a tropical climate and have surface water temperatures between $28^{\circ} \mathrm{C}$ $31^{\circ} \mathrm{C}$ which has a very good resource and potentially significant in ocean thermal energy.

The sea area in Indonesia is ideal for OTEC power plant because the surface of sea water temperature is high and almost constant throughout the year. This paper aim to determine the potential and the provision of new and renewable energy in Indonesia.

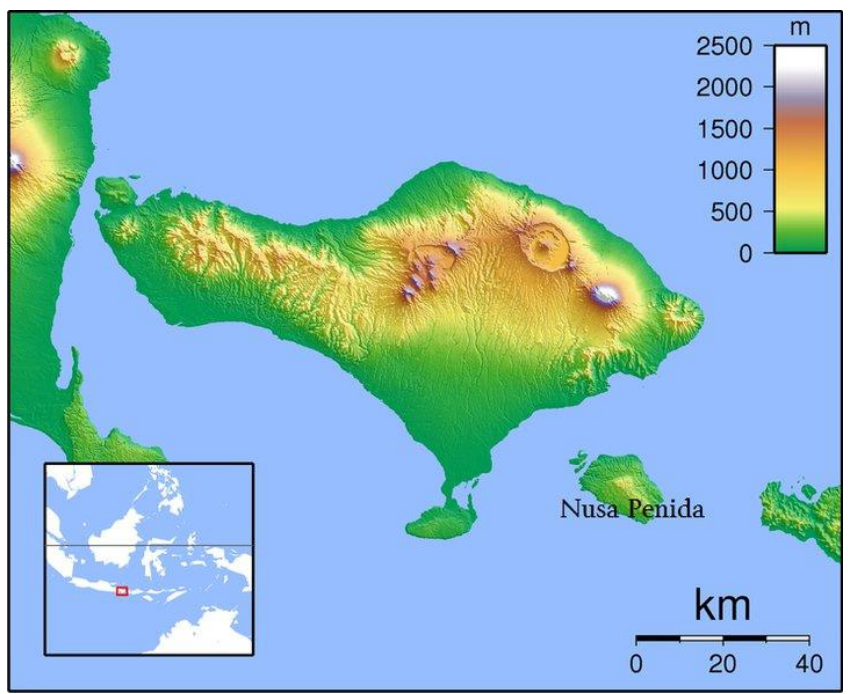

Fig. 1 Geographical location of Bali

"Corresponding author: Tel: +62-87868593161

E-mail: adrianrks@gmail.com 


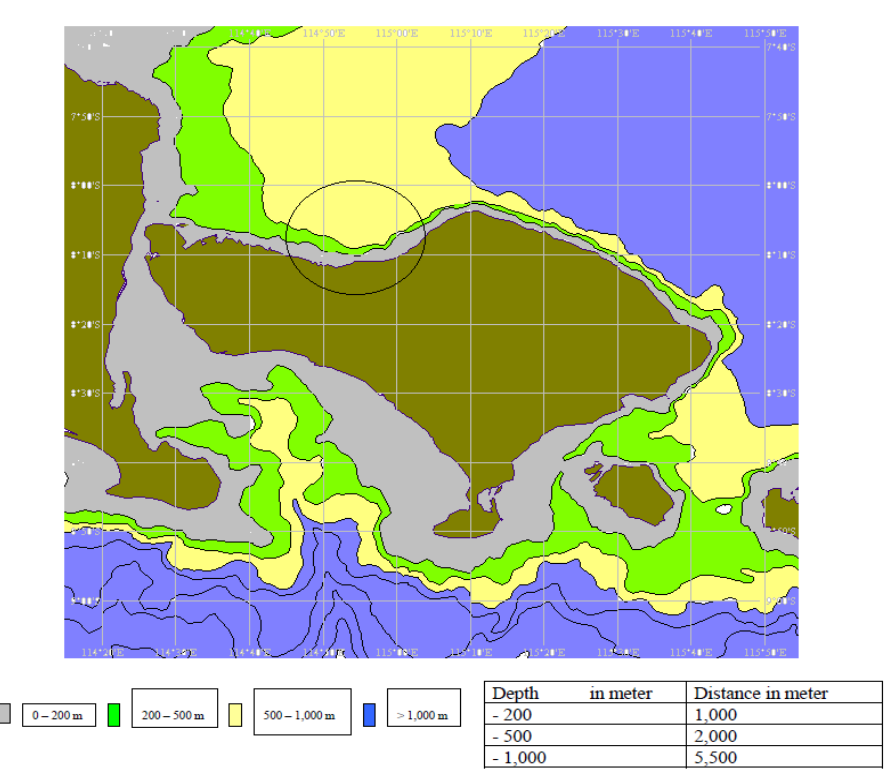

Fig. 2 Location map of OTEC in North Bali Sea

\section{Material and Method}

\subsection{OTEC Power System}

The OTEC system operates on a thermodynamic cycle, which uses the temperature differential between warm surface water (at $26^{\circ} \mathrm{C}$ or $79^{\circ} \mathrm{F}$ ) and substantially colder water (at $4^{\circ} \mathrm{C}$ or $39^{\circ} \mathrm{F}$ ) from the ocean depths. Apart from being able to use the differential to generate electricity, other useful by-products from the OTEC plant are fresh water, chilled water and nutrient-rich water. The system can be used in the OTEC are Open Cycle System and Closed cycle system.

\subsubsection{Thermodynamics Basic Process for OTEC}

OTEC systems rely on the basic relationship between pressure $(\mathrm{P})$, temperature $(\mathrm{T})$ and volume (V) of a fluid, which can be expressed by the following equation:

$$
\frac{\mathrm{PV}}{\mathrm{T}}=a \text { constan }
$$

where pressure, temperature and the volume of a fluid can be closely controlled by manipulating the other two variables. Hence the differential in temperature of the fluid can be used to create an increase in pressure in another. The increase in pressure is utilised to generate mechanical work. There are basically three types of OTEC systems developed that can utilise sea water temperature differentials - they are: a closed-cycle, an open-cycle and a hybrid-cycle.

\subsubsection{Closed-Cycle OTEC System}

The closed-cycle system uses a working fluid, such as ammonia, pumped around a closed loop, which has three components: a pump, turbine and heat exchanger (evaporator and condenser).Warm seawater passing through the evaporator converting the ammonia $^{1}$ liquid (4) into high-pressure ammonia vapour (5). The high-pressure at (1) vapour is then fed into an expander where it passes through and rotates a turbine connected to a generator. Low-pressure ammonia vapour leaving the turbine (2) is passed through a condenser, where the cold seawater cools the ammonia, returning the ammonia back into a liquid (3).

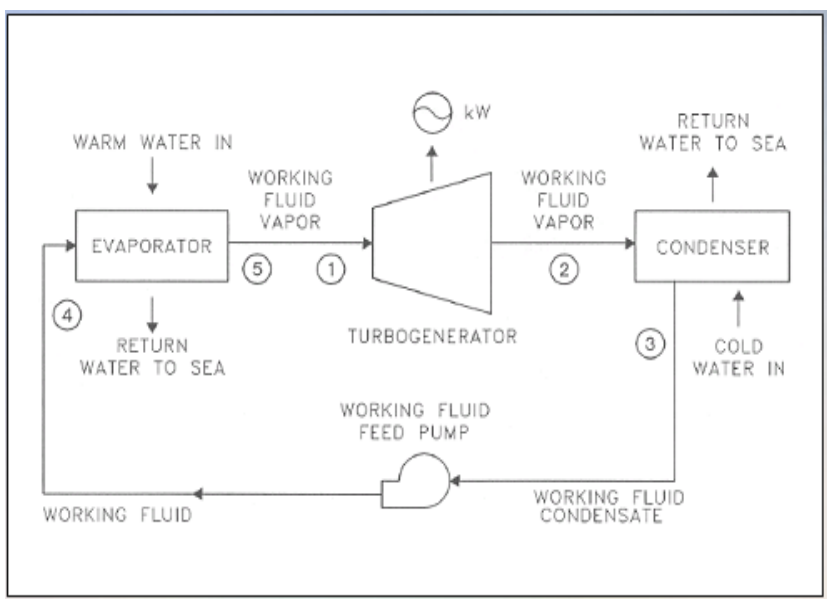

Fig. 3 Schematic of a closed-cycle OTEC system

Closed cyle is the process where heat use to evaporate the fluid on constant pressure in tank heater or evaporator which steam into the turbine and piston engine or expansion does work.The steam out enters into a container where the heat is transferred from the steam to coolant causing the steam is condensed into a liquid and the liquid is pumped back into the evaporator to complete the cycle. 


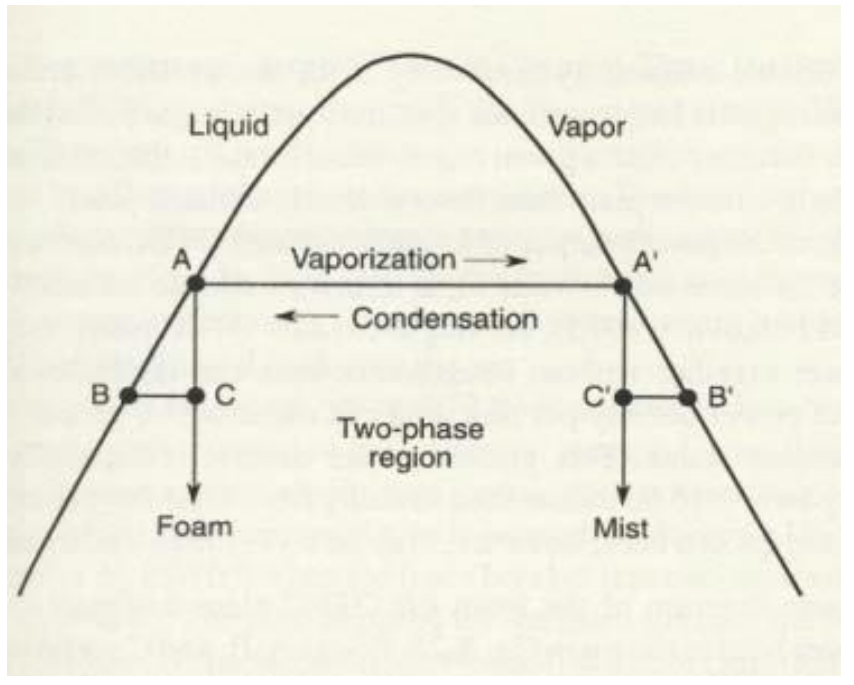

Fig. 4 Rankine cycle for OTEC system

\subsubsection{General equation of closed-cycle OTEC plant}

As referred to the T-s diagram in Fig. 5, pressure is assumed to be constant during heat addition to the evaporator, $(p 1=p 4)$ and heat extraction from the condenser $(p 2=p 3)$.

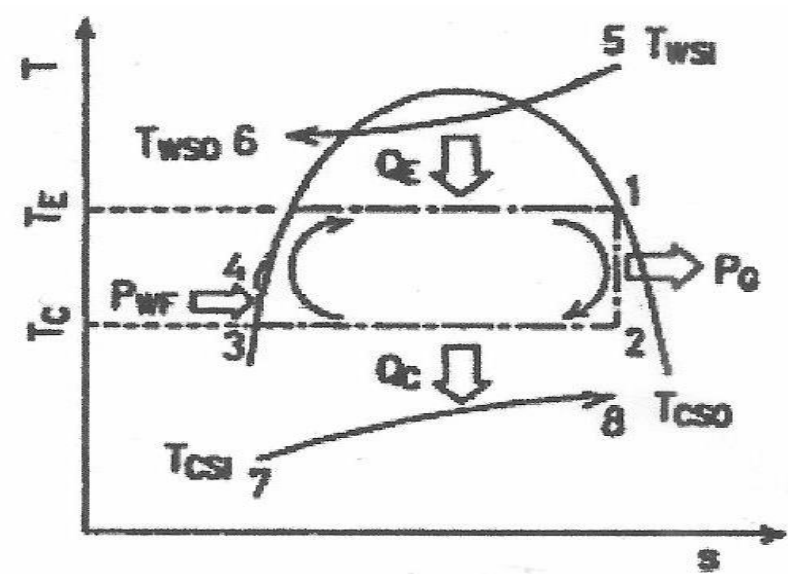

Fig. 5 T-s diagram of the closed Rankine Cycle

\subsubsection{Net Power}

The net power, $\mathrm{P}_{\mathrm{NET}}$, is given by:

$P_{N E T}=P_{T G}-\left(P_{W S W}+P_{C S W}+P_{W F}\right)$

where:

$P_{T G}=$ turbine generator power

$P_{W S W}=$ warm sea water pumping power

$P_{C S W}=$ the cold sea water pumping power

$P_{W F}=$ the working fluid pumping power

\subsubsection{Turbine Generator Power}

The turbine generator power $P_{T G}$ is given by:

$P_{T G}=m_{W F} \cdot \eta_{T} \cdot \eta_{G} \cdot\left(h_{1}-h_{2}\right)$

where :

$\mathrm{mWF}_{\mathrm{WF}}$ = mass flow rated of working fluid

$\eta_{T}=$ the turbine efficiency

$\eta_{G}=$ the generator efficiency

Efficiency of turbine is given as:

$\eta_{T}=\eta_{m} \cdot \eta_{e}$

where:

$\eta_{m}=$ mechanical efficiency

$\eta_{T}=$ theoretical efficiency

defined in reference as:

$$
\eta_{e}=\frac{H_{a d}-\left(\Delta h_{N}+\Delta h_{R}+\Delta h_{E x}+\Delta h_{D}+\Delta h_{W E T}\right)}{H_{a d}}
$$

where:

$\mathrm{h}_{\mathrm{AD}}=$ adiabatic heat drop

$\Delta \mathrm{h}_{\mathrm{N}}=$ kinetic energy loss in nozzle

$\Delta \mathrm{h}_{\mathrm{R}}=$ rotor loss

$\Delta \mathrm{h}_{\mathrm{EX}}=$ exhaust loss

$\Delta \mathrm{H}_{\mathrm{D}}=$ rotary disc loss due to disc fristion and windage $\Delta \mathrm{W}_{\mathrm{ET}}=$ losses due to wetnees of steam 


\subsubsection{Cold Sea Water Pumping Power}

The equation of cold sea water pumping power is given by:

$P_{C S W}=m_{C S W} \cdot v_{C S W} \cdot \Delta P_{C S W} / \eta_{C S P}$

where:

$m_{C S W}=$ mass flow rate of cold sea water

$v_{C S W}=$ specific volume of cold sea water

$\Delta P_{C S W}=$ total pressure difference of the cold sea water piping

$\eta_{C S P}=$ cold sea water pump efficiency

\subsubsection{Warm Sea Water Pumping Power} given by:

The warm sea water pumping power, $P_{W S W}$ is

$P_{w S W}=m_{w S w} \cdot v_{w s w} \cdot \Delta P_{w S W} / \eta_{w S P}$

$m_{W S W}=$ mass flow rate of warm sea water

$v_{W S W}=$ specific volume of the warm sea water

$\Delta P_{W S W}=$ total difference of the warm sea water piping $\eta_{W S P}=$ warm sea water pump efficiency

\subsubsection{Working Fluid Pumping Power}

The working fluid pumping power $P_{W F}$ is given by:

$P_{W F}=m_{W F} \cdot V_{W F} \cdot \Delta P_{W F} / \eta_{W F}$

\subsubsection{Heat Transfer Surface Area}

Evaporator and condenser (Heat exchanger) are the most important component of an OTEC power plant. In 1975, the shell-and-tube type heat exchanger (evaporator, condenser) were selected. The overall heat transfer coefficient is $3300 \mathrm{kcal} / \mathrm{m}^{2}$.h.OC. evaporator tube is the titanium and also condenser tube is the titanium.It was found by the cost estimation of the 1975 design that the total heat exchanger cost amounted to $45,7 \%$ of the plant construction cost. Improvement of the heat exchanger should be the most important item OTEC plant development. T. Uehara of Saga University was proposed use of new plate-type heat exchanger, based advanced technology.
The total heat transfer surface area, $A_{T}$, is gives by:

$A_{T}=A_{E V}+A_{C O N}$

where $A_{E V}$ and $A_{C O N}$ are the heat transfer areas of the evaporator and condenser. In this paper, the shell and plate-type heat exchanger is used as the evaporator and condenser. The heat transfer surface area of evaporator, $\mathrm{AEV}$, is given as:

$$
\begin{aligned}
A_{C O N} & =Q_{A E} /\left[U_{E V} \cdot(L M T D)_{E V}\right] \\
& =m_{W S W} \cdot C_{p} W S W \cdot\left(T_{W S W 1}-T_{W S W 0}\right) /\left[U_{E V}(L M T D)_{E V}\right]
\end{aligned}
$$

where:

$Q_{E V}=$ heat transfer rate of the evaporator

$(L M T D)_{E V}=$ logarithmic mean temperature difference of the evaporator

$U_{E V}=$ overall heat transfer coefficient.

$$
\begin{aligned}
A_{C O N} & =Q_{C O N} /\left[U_{C O N} \cdot(L M T D)_{C O N}\right] \\
& =m_{C S W} \cdot C_{p} C S W \cdot\left(T_{C W O}-T_{C S W 1}\right) /\left[U_{C O N}(L M T D)_{C O N}\right]
\end{aligned}
$$

where:

$Q_{C O N}=$ transfer rate of the condenser

$(L M T D)_{C O N}=$ logarithmic mean temperature difference of the condenser.

$Q_{E V}$ and $Q_{C O N}=$ heat transfer rate of the evaporator and condenser

respectively, defined as:

$$
\begin{aligned}
& Q_{E V}=m_{w s w} \cdot\left(h_{1}-h_{4}\right) \\
& Q_{C O N}=m_{C S w} \cdot\left(h_{2}-h_{3}\right)
\end{aligned}
$$

$h 1, h 4, h 2$ and $h 3$ are the enthalpy indicated by the four point in Figure 3. $m_{W F}$ is the working fluid (ammonia) flow rate is given by:

$m_{W F}=P_{G} / \eta_{T} \cdot \eta_{G}\left(h_{1}-h_{2}\right)$

Rankine cycle efficiency $\eta_{R}$ and the net Rankine cycle efficiency $\eta_{N E T}$ are given by:

$\eta_{R}=\mathrm{P}_{\mathrm{G}} / \mathrm{Q}_{\mathrm{E}}$

$\eta_{N E T}=P_{N E T} / Q_{E}$ 


\subsubsection{Open-Cycle OTEC System}

The open-cycle system is generally similar to the closed-cycle system and uses the same basic components. The open-cycle system uses the warm seawater as the working fluid. The warm seawater passing through the evaporator (2) is converted to steam (3), which drives the turbine/generator. After leaving the turbine (5), the steam is cooled by the cold seawater to form desalinated water. The desalinated water is pure fresh water for domestic and commercial use.

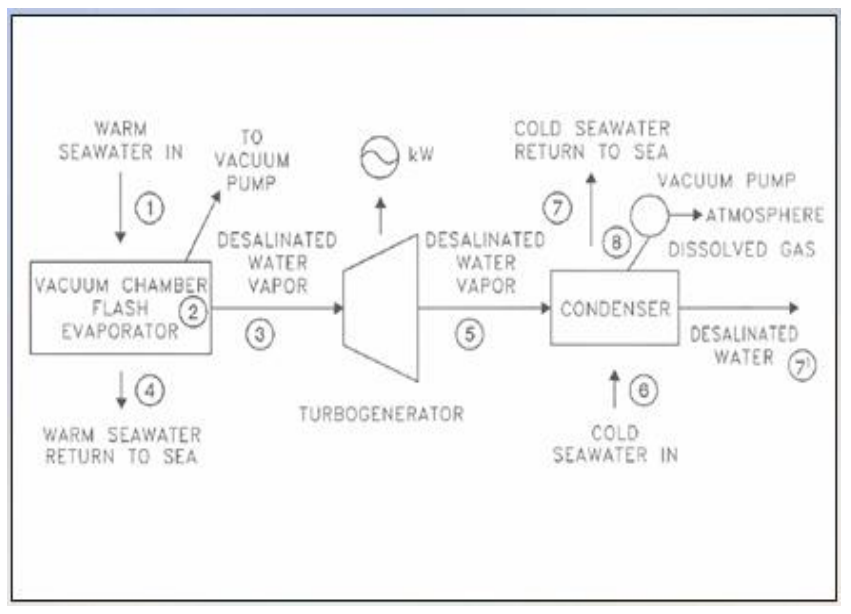

Fig. 6 Schematic of a open-cycle OTEC system

\subsubsection{Hybrid OTEC System}

The hybrid system uses parts of both open-cycle and closed-cycle systems to produce electricity and desalinated water. In this arrangement, electricity is generated in the closed cycle system and the warm and cold seawater discharges are passed through the flash evaporator and condenser of the open-cycle system to produce fresh water.

\subsection{OTEC Efficiency}

There is a theoretical limit, up to a maximum efficiency of an OTEC system by converting heat stored in the warm surface water of tropical oceans into mechanical work.

$$
\eta_{\max }=\frac{\mathrm{Tw}-\mathrm{Tc}}{\mathrm{Tw}}
$$

where:

$\eta_{\max }=$ maximum efficiency

$\mathrm{Tw}=$ absolute temperature from warm water

$\mathrm{Tc}=$ absolute temperature from cool water

For marine areas most suitable for OTEC operation, the average surface temperature of each annual is around $26.7^{\circ} \mathrm{C}$ to $29.4^{\circ} \mathrm{C}$. Cold water at $4.4^{\circ} \mathrm{C}$ or below is available at a depth of $900 \mathrm{~m}$. Therefore, the maximum efficiency of OTEC heat even without the inevitable reduction caused by friction and heat loss, can be achieved only at a very small rate of power production.

Efficiency is the ratio of energy or work in the system to the energy input into the system. Calculation method use to the equation relationship between sea surface temperature with depth, to compute the value of (b) as a function of the depth of the constants.

$X_{n}=X_{0}+B Y$

where:

$\mathrm{X}_{\mathrm{n}}=$ Temperature at depth $\mathrm{n}$

$\mathrm{X}_{0}=$ Initial surface temperature

$\mathrm{B}=$ Constants of a function of depth

$\mathrm{Y}=$ depth

\subsection{OTEC Plant Design and Location}

The location of a commercial OTEC plant has to be in an environment that is stable enough for an efficient system operation. The temperature differential at the site has to be at least $20^{\circ} \mathrm{C}\left(68^{\circ} \mathrm{F}\right)$. Generally the natural ocean thermal gradient necessary for OTEC operation is found between latitudes 20 degrees north and 20 degrees south.

Land-based OTEC plants do not require a sophisticated mooring system, lengthy power cables and more extensive maintenance as required with open ocean environment. In addition, the land-based sites allow OTEC to be associated with industries such as agriculture and those needing cooling and desalinated water.

The offshore or floating OTEC plant is another option. There are a number of difficulties associated 
with such a facility as it is difficult to stabilise the platform. The need for lengthy cables to deliver power and extra transportation to access the plant are added expenses.The plant is also more susceptible to damage especially during storms.

\section{Result and Discussion}

Based on data,surface water in north Bali sea X0 $=30.3^{\circ}$ (From: Balai Riset dan Observasi Kelautan $)$ and the calculated maximum depth is 600 meters.

Table 1

Calculation results of North Bali Sea

\begin{tabular}{|c|c|c|c|c|}
\hline No & Depth & B & X0 & Xn \\
\hline 1 & 0 & 0 & 30,3 & 30,3 \\
\hline 2 & 100 & $-0,047$ & 30,3 & 25,63 \\
\hline 3 & 200 & $-0,068$ & 30,3 & 16,74 \\
\hline 4 & 300 & $-0,061$ & 30,3 & 12,06 \\
\hline 5 & 400 & $-0,054$ & 30,3 & 8,78 \\
\hline 6 & 500 & $-0,047$ & 30,3 & 6,89 \\
\hline 7 & 600 & $-0,04$ & 30,3 & 6,4 \\
\hline
\end{tabular}

From data, we get surface water temperature and deep water in north Bali sea with $\mathrm{Tw}=30,30$ and $\mathrm{Tc}=$ 6,40 , so we can calculate efficiency from the equation of carnott efficiency so that :
Bali is a good regional for OTEC power plant because one of tourist areas. OTEC has important benefit other than power production, as by product of OTEC support chilled soil agriculture, aquaculture, fresh water, and OTEC power plant is not source of environmental pollution.

$$
\begin{aligned}
\eta_{\max } & =\frac{\mathrm{Tw}-\mathrm{Tc}}{\mathrm{Tw}} \\
\eta_{\max } & =\frac{30,30-6,40}{30,30}
\end{aligned}
$$$$
\eta_{\max }=0,788813
$$

This is very good efficiency than other areas so that north sea of Bali is the most potential in the development of sea surface water temperatures for OTEC. If it take $100 \mathrm{KW}$ for input power and carnot efficiency 0,788813 so net power become 78,8813 KW.

If Indonesian annual mean value of sea water temperature is taken, the data energy calculations, namely:

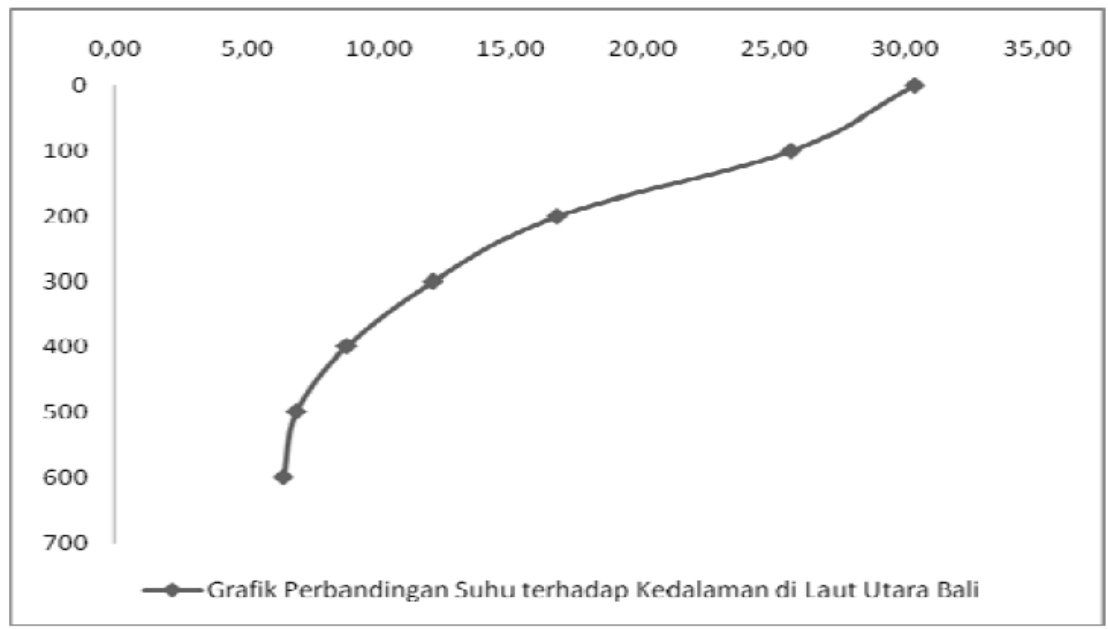

Fig. 7 Comparison of temperature against depth chart in north Bali sea 
Table 2

Condition of Calculation Data of OTEC Plant Proposed

\begin{tabular}{|c|c|c|c|}
\hline Generator Power & $P_{G}$ & $\mathrm{~kW}$ & 120 \\
\hline Turbine efficiency & $\eta_{T}$ & - & 0.82 \\
\hline Generator efficiency & $\eta_{G}$ & - & 0.95 \\
\hline Warm sea water pump efficiency & $\eta_{W S P}$ & - & 0.80 \\
\hline Cold sea water pump efficiency & $\eta_{C S P}$ & - & 0.80 \\
\hline Working fluid pump efficiency & $\eta_{W F}$ & - & 0.75 \\
\hline $\begin{array}{l}\text { Evaporator (plate-type heat exchanger) } \\
\text { overall heat transfer coefficient } \\
\mathrm{T}_{\mathrm{WSW} 1}-\mathrm{T}_{\mathrm{EV}}\end{array}$ & $\mathrm{UEV}_{\mathrm{EV}}$ & $\mathrm{m}_{\mathrm{K}}^{2} \cdot \mathrm{K}$ & $\begin{array}{r}4000 \\
4.0\end{array}$ \\
\hline $\begin{array}{l}\text { Condenser (plate-type heat exchanger) } \\
\text { overall heat transfer coefficient } \\
\mathrm{T}_{\mathrm{C}}-\mathrm{T}_{\mathrm{Wsw} 1}\end{array}$ & $\mathrm{U}_{\text {CON }}$ & $\begin{array}{c}\mathrm{m} / \mathrm{K} \\
\mathrm{K} \\
\end{array}$ & $\begin{array}{r}3500 \\
4.0 \\
\end{array}$ \\
\hline $\begin{array}{l}\text { Sea water temperature } \\
\text { (Annual mean value in Indonesia) } \\
\text { - Warm sea water temperature at depth } 0 \mathrm{~m} \\
\text { - Cold sea water temperature at depth } 1000 \mathrm{~m}\end{array}$ & & $\begin{array}{l}{ }^{\circ} \mathrm{C} \\
{ }^{\circ} \mathrm{C}\end{array}$ & $\begin{array}{c}26 \\
5 \\
\end{array}$ \\
\hline
\end{tabular}

\section{Table 3}

Calculation results of $125 \mathrm{kWe}$ OTEC

Warm sea water inlet temperature

Warm sea water outlet temperature

Cold sea water inlet temperature

Cold sea water outlet temperature

Evaporation temperature

Condenser temperature

Net power

Warm sea water pumping power

Cold sea water pumping power

Working fluid pumping power

Warm sea water flow rate

Cold sea water flow rate

Working fluid flow rate

Heat flow rate of evaporator

Heat flow rate of condenser

Logarithmic mean temperature differences

Logarithmic mean temperature differences

Heat transfer area of evaporator

Heat transfer area of condenser

Rankine cycle efficiency

Net Rankine cycle efficiency

\begin{tabular}{lll}
$\mathrm{T}_{\text {WSNI }}$ & $\left({ }^{\circ} \mathrm{C}\right)$ & 26.5 \\
$\mathrm{~T}_{\text {WSNO }}$ & $\left({ }^{\circ} \mathrm{C}\right)$ & 23.0 \\
$\mathrm{~T}_{\mathrm{CSWI}}$ & $\left({ }^{\circ} \mathrm{C}\right)$ & 6.0 \\
$\mathrm{~T}_{\mathrm{CSWO}}$ & $\left({ }^{\circ} \mathrm{C}\right)$ & 8.0 \\
$\mathrm{~T}_{\text {EV }}$ & $\left({ }^{\circ} \mathrm{C}\right)$ & 22.0 \\
$\mathrm{~T}_{\mathrm{CON}}$ & $\left({ }^{\circ} \mathrm{C}\right)$ & 10.0 \\
$\mathrm{P}_{\mathrm{NET}}$ & $(\mathrm{kW})$ & 69.4 \\
$\mathrm{P}_{\mathrm{WSW}}$ & $(\mathrm{kW})$ & 20.4 \\
$\mathrm{P}_{\mathrm{CSW}}$ & $(\mathrm{kW})$ & 30.75 \\
$\mathrm{P}_{\mathrm{WF}}$ & $(\mathrm{kW})$ & 4.41 \\
$\mathrm{~m}_{\mathrm{SWW}}$ & $\mathrm{Kg} / \mathrm{s}$ & 325.25 \\
$\mathrm{~m}_{\mathrm{CSW}}$ & $\mathrm{Kg} / \mathrm{s}$ & 4920 \\
$\mathrm{~m}_{\mathrm{WF}}$ & $\mathrm{Kg} / \mathrm{s}$ & 3467 \\
\hline $\mathrm{Q}_{\mathrm{EV}}$ & $\mathrm{kW}$ & 4085.3 \\
$\mathrm{Q}_{\mathrm{CON}}$ & $\mathrm{kW}$ & 4119.3 \\
\hline $\mathrm{LMTD}_{\mathrm{EV}}$ & ${ }^{\circ} \mathrm{C}$ & 4.37 \\
$\mathrm{LMTD}_{\mathrm{CON}}$ & ${ }^{\circ} \mathrm{C}$ & 2.89 \\
\hline $\mathrm{A}_{\mathrm{EV}}$ & $\mathrm{m}^{2}$ & 236.0 \\
$\mathrm{~A}_{\mathrm{CON}}$ & $\mathrm{m}^{2}$ & 407.0 \\
$\eta_{\mathrm{R}}$ & $\%$ & 3.1 \\
$\eta_{\text {net }}$ & $\%$ & 2.0 \\
\hline & &
\end{tabular}

OTEC power comparable with other power plants such as wave, hydro and diesel. However, it is important that all capital costs and on going maintenance/service costs

are included so that the individual technologies are compared on a level playing field.

Table 4

Comparison of Unit Cost of OTEC with Conventional Energy Sources

\begin{tabular}{|l|c|c|c|c|c|}
\hline & Plant capacity & Plant Life(Years) & Capacity Factor(\%) & Annual Output(GWh) & Cost of Energy(US\$/kWh) \\
\hline Wave & 1.5 & 40 & 68 & 9 & $0.062-0.072$ \\
\hline Hydro & 1.2 & 40 & 48 & 5 & 0.113 \\
\hline Diesel & 0.9 & 20 & 64 & 5 & 0.126 \\
\hline OTEC & 1.256 & 30 & 80 & 8.8 & 0.149 \\
\hline
\end{tabular}




\section{Conclusion}

North Bali sea is ideal for OTEC power plant to generate electricity for small islands, because the sea areas in Indonesia have average monthly temperature difference between $28^{\circ} \mathrm{C}-31^{\circ} \mathrm{C}$ and maximum carnott efficiency is 0,788813 .

OTEC uses clean, abundant, renewable and natural resources to produce electricity. Research indicates that there are little or no adverse environmental effects from discharging the used OTEC water back to the ocean at prescribed depths.

As well as producing electricity, OTEC systems can produce fresh water and cold water for agricultural and cooling purposes. The use of OTEC also assists in reducing the dependence on fossil fuels to produce electricity. This is really important because Bali is a tourist area.

The OTEC technology is perhaps the promising solution to meeting some of the region's increasing energy requirements thus,reducing the need to import petroleum products. More comprehensive research and study needed to know the possibility location for OTEC to built and estimated cost.

\section{Acknowledgements}

The author really grateful my lecture, Mr Dicky Muslim who help me to finish this paper. The author would like to thank the proof reader participants, fellow honors student, supportive friends and family, all sources about OTEC and EBTKE CONEX

\section{References}

Apllied Phsysics Lab., SR-80-2A.B,c. Oct. General Electric. 1983. Closed cycle OTEC power plant final report. General Electric Co.

Blevins, R. W. H. L. Donnelly and J.T. Stadler,1980. Verification test for cold water pipe anlysis. Johns Hopkins Univ.
Hiroshi Kamogawa. 1980. OTEC Research in Japan. Energy/Pergamon Press Ltd. Vol. 5. pp 481-192. Japan.

Hörmandinger G and Lucas N; Excerpts from "Is Clean enough? - The influence of environmental externalities on markets for fuel cells in transport"; Centre for Environmental Technology, Imperial College, London, 1996

McGuiness, T.1982. "Some ocean engineering considerations in the design of OTEC plants". Proc. IECEC'82 17th Intersociety Engineering Conf.,3.1423.

Noburu Yamada and Yasuyuki Ikegami. 28-29 June. Thermal Efficiency Enhancement of Ocean Thermal Energy Conversion (OTEC) Using Solar Thermal Energy. 4 th International Energy Conversion Engineering Conference and Exhibit (IECEC). San Diego California

Nutall, L.J.1981. "Advance water electrolysis technology for efficient utilization ocean thermal energy". Proc. 8th Ocean Energy Conf., Washington, D.C.,6,625.

Rahman, Y. 2008. OTEC : Ocean Thermal Energy Conversion. Institut Teknologi Bandung Press. Bandung

Salam, L and Siahaya, Y.09-11 December.Ocean Thermal Energy Conversion Power Plant and it's by products yield for small islands in Indonesia sea water. ICCHT-5th International Conference on Cooling and Heating Technologies. Bandung

Schenectady, N.Y.Avery, W. H. Wu, Chih. 1994. Renewable energy from the ocean : a guide to OTEC. Oxford University Press, Inc.New York.

Sims, Calvin. Steam System May Improve Power Plant. Cambridge University Press. Cambridge

Surinati, Dewi. 2009. Kondisi Oseanografi Fisikia Perairan Barat Sumatra (Pulau Simeulue dan Sekitarnya) Pada Bulan Agustus 2007 Pasca Tsunami 2004. Bidang Dinamika Laut, Pusat Penilitan Oseanografi, LIPI. Jakarta Utara.

Thomas H. D; Ocean Thermal Energy Conversion: An Extensive, Environmentally Benign Source of Energy for the Future, Natural Energy Laboratory of Hawaii Authority, in "Sustainable Development International; Strategies and Technologies for Agenda 21 Implementation"; Third Edition, ICG Publishing Ltd, London, 2000.

Uehara, H and Ikegami, Y. 1990. Optimization of Closed-Cycle OTEC System. Trans of the ASME Journal of Solar Energy Engineering. pp 112-4, 247-256.

Uehara, H et al.1988. Conceptual Design of Ocean Thermal Energy Conversion (OTEC) Power Plants in the Philipines. Pergamon Press.U.S.A

Wu, C. 1987. "A performance bound for real OTEC heat engines". Ocean engineering, 24,349.

Yasamobu Nakamoto, and Mikio Takayanagi. November, December 1982. OTEC Development in Toshiba. Toshiba Review No 142 